\title{
The Relationship between Maternal Acceptance-Rejection Levels and Preschoolers' Social Competence and Emotion Regulation Skills
}

\author{
Dilan Bayındır ${ }^{1}$, Gülçin Güven ${ }^{2}$, Türker Sezer ${ }^{3}$, Ezgi Akşin-Yavuz ${ }^{4}$ \& Elif Yılmaz ${ }^{5}$ \\ ${ }^{1}$ Department of Primary Education, Balıkesir University, Turkey \\ ${ }^{2}$ Department of Primary Education, Marmara University, Turkey \\ ${ }^{3}$ Department of Primary Education, Abant Izzet Baysal University, Turkey \\ ${ }^{4}$ Department of Primary Education, Trakya University, Turkey \\ ${ }^{5}$ Department of Primary Education, Karamanoğlu Mehmetbey University, Turkey \\ Correspondence: Dilan Bayındır, Department of Primary Education, Necatibey Faculty of Education, Balıkesir \\ University, Balıkesir, Turkey. E-mail: dilanbayindir@gmail.com
}

Received: January 10, 2017

Accepted: January 31, 2017

Online Published: March 7, 2017

doi:10.5539/jel.v6n2p305

URL: http://doi.org/10.5539/jel.v6n2p305

This study was presented at the $8^{\text {th }}$ World Conference on Educational Sciences, which was held between 4-8 February 2016 at University of Alcala.

\begin{abstract}
The purpose of this research was to examine the relationship between maternal acceptance-rejection levels and preschool children's social competence and emotion regulation skills. The study group of the research, which was designed in survey method, consisted of 303 voluntary mother-child dyad. The participant children were attending a preschool in 2014-2015 academic year, in Istanbul and they were selected by random cluster sampling method. The "Personal Information Form", the "Parental Acceptance-Rejection Questionnaire-Mother Form (PARQ)", the "Social Competence and Behavior Evaluation-30 (SCBE-30)" and the "Emotion Regulation Checklist" were used as data collection tools.

As a result of the study, it has been found that there is a positive significant relationship between maternal acceptance level and children's "Social Competence" subscale of SCBE-30 and their emotional regulation skills. In addition to this result, it has been found that maternal acceptance level didn't differentiated according to age and gender of the child; however the average scores of PARQ's "Warmth/Affection" subscale have been differentiated in favor of the girls. It has been found that "Social Competence" and "Anger-Aggression" subscales of SCBE-30 were significantly differentiated according to gender; "Anger-Aggression" scores of the boys were higher than the girls, whereas "Social Competence" scores of the girls were higher than the boys. Moreover, it has been found that "Lability-Negativity" subscale scores of Emotion Regulation Checklist have been differentiated according to gender; girls showing less labile/negative emotional reactions. Finally, it has been found that child's social competence and emotional regulation skills increase as the age increases.
\end{abstract}

Keywords: maternal acceptance-rejection, social competence, emotion regulation, preschool period

\section{Introduction}

There are many studies showing that parenting characteristics are related to the child's social development (Bigras \& Dessen, 2002; Bohlin, Hagekull, \& Anderson, 2005; Ladd, 1999; Tepeli \& Y1lmaz, 2013) and emotion regulation skills (Altan, 2006; Gilliom, Shaw, Beck, Schonberg, \& Lukon, 2002; Hardy, Power, \& Jaedicke, 1993; Kliewer, Fearnow, \& Miller 1996; Metin, 2010; Tepeli, Yılmaz, \& Kuyucu, 2014). One of the focus of the parenting studies is parental acceptance. Parental Acceptance-Rejection Theory (Rohner, 1984) provides a framework for studies investigate the effects of the parental acceptance for child's well being. Parental Acceptance-Rejection Theory (PARTheory) argues that people need to get positive responses from the individuals who are important to them. Accordingly, the most basic needs of children are the care, comfort, support and love that will be provided by their parents. The whole humanity has this need, regardless of culture, race, physical characteristics, social status, language, geography and the other similar restrictive conditions 
(Khaleque \& Rohner, 2002). Rohner's (2004) definition of parental acceptance and rejection form the warmth dimension of parenting. Researches in 1990 have indicated the effects of parental warmth on the psychological, social and educational development of the child (Lamb, 1997; cited in Veneziano, 2000). In Turkey, researches conducted with children have showed that parental acceptance is correlated with high social competence (Kasuto, 2005; Gülay, 2011), acceptance among peers (Gülay-Ogelman \& Uçar-Çabuk, 2013), problem solving skills (Tepeli \& Y1lmaz, 2013), and emotion comprehension skills (Tepeli et al., 2014).

During the preschool period, the social aim that children are expected to achieve is acquiring social competence. Cavell, Meehan and Fiala (2003) define social competence as a construct consisting of social harmony, social performance and social skills (cited in Arslan-Yalçın, 2009). The child's social skills are expected to increase as the age increases (Çorapçı, Aksan, Arslan-Yalçın, \& Yağmurlu, 2010; Rose-Krasnor, 1997; Yılmaz \& Tepeli, 2013). In addition, the results of the researches addressing gender variable revealed that girls' social competence levels are higher than boys, they show more prosocial behaviors compared to the boys (Arslan-Yalçın, 2009; Çorapçı et al., 2010; Diener \& Kim, 2004; LaFreniere et al., 2002). The attitudes and behaviors of the family is one of the important variables on the development of social behavior. Children's social competency behavior is positively correlated with the maternal sensitivity, consistency, tendency to speak about her feelings, whereas it is negatively correlated with negative and rigid parental behaviors (Bigras \& Dessen, 2002; Bohlin et al., 2005; Ladd, 1999; Whiteside-Mansell, Bradley, \& McKelvey, 2009). The families' social values and aims that shape the child rearing practices could be changed among cultures and by time (Papps, Walker, \& Trimboli, 1995).

There are many studies stressing the strong link between social skills and emotional skills (Lemerise \& Arsenio, 2000; Ashiabi, 2000). Eisenberg, Pidada and Liew (2001) found that high emotion regulation skills leaded to high social competency and less behavioral problem. Emotion regulation skill includes the adaptation of emotional reactions according to the environment (Thompson, 1994; cited in Çorapçı et al., 2010). It has been found that the shortcomings of emotion regulation skill are related to externalization and internalization problems (Eisenberg et al., 2001; Eisenberg et al., 2004; Rydell, Berlin, \& Bohlin, 2003), lack to acting empathetically (Eisenberg et al., 2004) and low prosocial behavior (Rydell et al., 2003).

The studies conducted in the development field underline that emotional regulation exists even in the first years of the life (Kopp, 1989) and it is developed through family-child interaction (Fox \& Calkins, 2003). According to Morris, Silk, Steinberg, Myers and Robinson (2007), children develop their own skills by observing their parents' emotion regulation behaviors and modeling them. Children, whose mothers showed higher acceptance and approval, use very different strategies to handle emotional problems (Hardy et al., 1993). Similarly, studies done with Turkish samples figured out that the maternal care is a predictor of children's emotion regulation skills (Altan, 2006; Metin, 2010). Literature shows that emotional regulation skills of the girls are higher than the boys (Cole, Zahn-Waxler, \& Smith, 1994). These results might have been emerged due to the social gender roles (Dion \& Yee, 1987; Cole et al., 1994). This fact is also pointing the role of cultural differences on emotion regulation skills. In collectivist cultures, the disclosure of negative emotions is not considered to be appropriate; whereas it is considered to be worthy in individualistic cultures (Matsumoto, Hee-Yoo, \& Chung, 2007; cited in Metin, 2010). The findings of Zahn-Waxler, Friedman, Cole, Mizute and Hiruma (1996) support this view; they have found that in case of conflict and difficulty, American preschool children showed more anger and less emotion regulation compared to Japanese children.

As the relevant literature, which has been outlined above, indicates that although there are studies were conducted about parental acceptance-rejection, social competence and emotional regulation, the relation between these variables needs to be tested in different cultural contexts. So, this research aims to examine the relationship between maternal acceptance-rejection levels and preschool children's social competence and emotion regulation skills and provide a holistic data between these variables that are known to be associated with each other. In this context, the current study investigated the following research questions: (1) Is there a significant difference between girls' and boys' level of maternal acceptance-rejection, their social competence and emotion regulation skills? (2) Is there a difference between 5 year and 6 year olds' level of maternal acceptance-rejection, their social competence and emotion regulation skills? (3) Is there a significant relationship between matrenal acceptance-rejection levels and children's social competence? (4) Is there a significant relationship between maternal acceptance-rejection levels and children's emotion regulation skills? 


\section{Methodology}

\subsection{Research Model}

The research which investigates the relationship between maternal acceptance-rejection levels and children's social competence and emotional regulation skills was introduced in survey model.

\subsection{Study Group}

The study group of this research consisted of 303 mother-child dyad. The participant children were attending a preschool in 2014-2015 academic year, in Istanbul. 52.6\% of the children are girls, whereas $47.4 \%$ are boys and $37.6 \%$ of the children are 5 years old whereas $62.4 \%$ are 6 years old.

The age distribution of the mothers is as follows: $1.3 \%$ are $18-28$ years old, $40.4 \%$ are $26-33$ years old, $50.7 \%$ are 34-41 years old and 7.6\% are 42 and above. The distributions of their educational levels is as follows: 5.2\% are primary school, $6.9 \%$ are secondary school, $30.3 \%$ are high school graduates and $13.8 \%$ have associate degrees, $36.6 \%$ have bachelor degrees and $7.2 \%$ have masters degrees. $44 \%$ of the mothers have one child, $48.7 \%$ have two children and $7.3 \%$ have three or more children.

\subsection{Data Collection Tools}

Within the scope of the research, the tools used for data collection were Personal Information Form, Parental Acceptance-Rejection Questionnaire-Mother Form (PARQ), Social Competence and Behavior Evaluation-30 (SCBE-30) and Emotion Regulation Checklist.

\subsubsection{Personal Information Form}

This form was developed by the researchers who participated in this study and it has been used to obtain demographic information (age, gender, mother's education, income) about the mothers and children in the study group.

\subsubsection{Parental Acceptance-Rejection Questionnaire (Mother Form)}

Parental Acceptance-Rejection Questionnaire-Mother Form was developed by Rohner, Saavedra and Granum in 1980 and adapted into Turkish by Anjel and Erkman in 1993. This questionnaire, which can be filled out by the mothers with children 3 year old or older, measures maternal acceptance and rejection as perceived by the mother; it consists of 56 likert-type items and four subscales, namely "Warmth/Affection" (20 items), "Hostility/Aggression" (16 items), "Indifference/Neglect" (12 items) and "Undifferentiated Rejection" (8 items). High scores achieved from the subscales and high overall score indicate high level of rejection. As the level of rejection increases, mother's child rejection increases and her child acceptance decreases (Öner, 2012). Anjel (1993) tested the validity and the reliability of the scale. The alpha value that was found after the Kuder Richardson analysis was .90 .

\subsubsection{Social Competence and Behavior Evaluation-30 (SCBE-30)}

The Social Competence and Behavior Evaluation-30 (SCBE-30) was developed by LaFreniere and Dumas (1996) and adapted to Turkish by Çorapçı and her collegues (2010). It includes 30 items evaluating preschool children's problematic symptoms and the magnitude of their social skills under three subscales, namely "Social Competence", "Anger-Aggression" and "Anxiety-Withdrawal". "Social Competence" subscale measures children's positive behaviors such as the cooperation and seeking solutions to conflicts when they are with their peers. "Anger-Aggression" evaluates the symptoms of externalization problems, such as being recalcitrant against adults and behaving incompatibly and aggressively in peer relationships; whereas "Anxiety-Withdrawal" evaluates sad, depressive mood of the children and the symptoms of internalization problems, such as timidity within a group. It is a 6-point Likert scale and it can be filled by the teacher or a parent. The Cronbach Alfa values of each subscales of the Turkish form were found as .88 for social competence, .87 for anger-agression and .84 for anxiety-withdrawal (Çorapçı et al., 2010).

\subsubsection{Emotion Regulation Checklist}

Emotion Regulation Checklist was developed by Shields and Cicchetti (1997), its adaptation to Turkish was performed by Batum and Yağmurlu (2007). The checklist consists of 24 items that evaluate emotional reactivity of preschool and school children and their regulation and expression of their emotions according to the conditions of the environment; it includes two subscales, namely "Emotion Regulation" and "Lability-Negativity". It is a 4-point likert scale and it can be filled by the teacher or a parent. The related literature indicate the scale is a valid and reliable one (Miller et al., 2006; Shields \& Cicchetti, 1997). The 
internal consistency value of mother evaluations was found as .75 and the value of teacher evaluations was .84 (Yağmurlu \& Altan, 2010).

\subsection{Data Collection and Analysis}

The study group of the research consisted of 303 mother-child dyad who were attending a pre-school educational institution during 2014-2015 academic years, in Anatolian side of Istanbul; they were selected by random sampling and they have participated in the research voluntarily. "Personal Information Form" and "Parental Acceptance-Rejection Questionnaire-Mother Form" were filled by the mothers of the children in the workgroup, whereas "Social Competence and Behavior Evaluation-30" and "Emotion Regulation Checklist" were filled by the teachers of these children. The obtained data were analyzed by Pearson correlation test and t-test using appropriate statistics software. The significance level of the analysis was taken as $p<.05$.

\section{Findings}

This part contains the findings obtained at the end of the research. First of all, the results of the t-test, where children's social competence and emotional regulation skills and maternal acceptance-rejection levels were analyzed according to gender, are presented in Table 1.

Table 1. T-test results of maternal acceptance-rejection levels and children's social competence and emotional regulation skills according to gender

\begin{tabular}{|c|c|c|c|c|c|c|c|c|}
\hline & Subscales & Gender & $\mathrm{n}$ & $\overline{\mathrm{X}}$ & SD & SS & $\mathrm{t}$ & $\mathrm{p}$ \\
\hline \multirow{10}{*}{$\begin{array}{c}\text { Parental } \\
\text { Acceptance-Rejection } \\
\text { Questionnaire - } \\
\text { Mother Form }\end{array}$} & \multirow{2}{*}{ Warmth and Affection } & Girl & 159 & 25.35 & 3.797 & 300 & -2.187 & $.029 *$ \\
\hline & & Boy & 144 & 26.48 & 5.141 & & & \\
\hline & \multirow{2}{*}{ Hostility and Aggression } & Girl & 159 & 22.23 & 5.004 & 300 & .244 & .807 \\
\hline & & Boy & 144 & 22.09 & 5.527 & & & \\
\hline & \multirow{2}{*}{ Indifference and Neglect } & Girl & 159 & 14.69 & 2.808 & 300 & -1.447 & .149 \\
\hline & & Boy & 144 & 15.20 & 3.326 & & & \\
\hline & Undifferentiated & Girl & 159 & 11.03 & 2.442 & 300 & .508 & .612 \\
\hline & \multirow[t]{2}{*}{ Rejection } & Boy & 144 & 10.88 & 2.699 & & & \\
\hline & & Girl & 159 & 73.31 & 10.483 & 300 & -1.004 & .316 \\
\hline & Total Score & Boy & 144 & 74.65 & 12.744 & & & \\
\hline \multirow{6}{*}{$\begin{array}{c}\text { Social Competence } \\
\text { and Behavior } \\
\text { Evaluation-30 }\end{array}$} & \multirow{2}{*}{ Social Competence } & Girl & 159 & 48.14 & 8.880 & 300 & 2.926 & $.004 * *$ \\
\hline & & Boy & 144 & 44.99 & 9.837 & & & \\
\hline & \multirow{2}{*}{ Anger-Aggression } & Girl & 159 & 17.83 & 7.582 & 300 & -2.429 & $.016^{*}$ \\
\hline & & Boy & 144 & 20.35 & 10.399 & & & \\
\hline & \multirow{2}{*}{ Anxiety-Withdrawal } & Girl & 159 & 19.84 & 8.794 & 300 & 1.106 & .269 \\
\hline & & Boy & 144 & 18.79 & 7.723 & & & \\
\hline \multirow{4}{*}{$\begin{array}{c}\text { Emotion Regulation } \\
\text { Checklist }\end{array}$} & \multirow{2}{*}{ Emotion Regulation } & Girl & 159 & 25.20 & 4.076 & 300 & .735 & .463 \\
\hline & & Boy & 144 & 24.85 & 4.148 & & & \\
\hline & \multirow{2}{*}{ Lability-Negativity } & Girl & 159 & 24.69 & 6.630 & 300 & -3.258 & $.001 * *$ \\
\hline & & Boy & 144 & 27.45 & 8.092 & & & \\
\hline
\end{tabular}

${ }^{*} \mathrm{p}<.05 ; * * \mathrm{p}<.01$

According to Table 1, average scores of the mothers did not differentiated in terms of overall parental acceptance-rejection score, "Hostility/Aggression", "Indifference/Neglect" and "Undifferentiated Rejection" according to gender ( $p>05)$. On the other hand, a significant difference has been identified for "Warmth and Affection" subscale of Parental Acceptance-Rejection Questionnaire in favor of the girls $(\mathrm{p}<.05)$.

It has been found that "Social Competence" and "Anger-Aggression" subscales' scores of Social Competence and Behavior Evaluation-30 have been significantly differentiated according to gender whereas there is no 
significant differences on "Anxiety-Withdrawal" subscale ( $p>.05$ ). Accordingly, higher scores of "Social Competence" subscale means higher social skills and the findings indicate that the difference is in favor of the girls. Higher scores of "Anger-Aggression" subscale means more angry and aggressive behaviors, thus it has been interpreted as that boys display angry and aggressive behaviors more than girls.

It has been found that there was no significant difference on the average scores of "Emotion Regulation" subscale of Emotion Regulation Checklist according to gender ( $p>05$ ). However, a significant difference has been identified for "Lability-Negativity" subscale in favor of the girls, means the girls indicate less lability/negativity than boys $(\mathrm{p}<.01)$.

Table 2. T-test results of maternal acceptance-rejection levels and children's social competence and emotional regulation skills according to age

\begin{tabular}{|c|c|c|c|c|c|c|c|c|}
\hline & Subscales & Age & $\mathrm{n}$ & $\overline{\mathrm{X}}$ & SD & SS & $\mathrm{t}$ & $\mathrm{p}$ \\
\hline \multirow{6}{*}{$\begin{array}{l}\text { Parental } \\
\text { Acceptance-Rejection } \\
\text { Questionnaire - Mother }\end{array}$} & \multirow{2}{*}{ Warmth and Affection } & $5 \mathrm{y} / \mathrm{o}$ & 114 & 25.67 & 4.066 & 301 & -.617 & .538 \\
\hline & & $6 \mathrm{y} / \mathrm{o}$ & 189 & 26.00 & 4.757 & & & \\
\hline & \multirow{2}{*}{ Hostility and Aggression } & $5 \mathrm{y} / 0$ & 114 & 22.27 & 5.640 & 301 & .267 & .790 \\
\hline & & $6 \mathrm{y} / \mathrm{o}$ & 189 & 22.10 & 4.999 & & & \\
\hline & \multirow{2}{*}{ Indifference and Neglect } & $5 \mathrm{y} / 0$ & 114 & 15.03 & 3.301 & 301 & .325 & .745 \\
\hline & & $6 \mathrm{y} / \mathrm{o}$ & 189 & 14.91 & 2.979 & & & \\
\hline \multirow[t]{6}{*}{ Form } & Undifferentiated & $5 \mathrm{y} / \mathrm{o}$ & 114 & 10.85 & 2.565 & 301 & -.549 & .584 \\
\hline & Rejection & $6 \mathrm{y} / \mathrm{o}$ & 189 & 11.02 & 2.562 & & & \\
\hline & \multirow{2}{*}{ Total Score } & $5 \mathrm{y} / \mathrm{o}$ & 114 & 73.84 & 12.505 & 301 & -.153 & .878 \\
\hline & & $6 \mathrm{y} / \mathrm{o}$ & 189 & 74.05 & 11.045 & & & \\
\hline & \multirow{2}{*}{ Social Competence } & $5 \mathrm{y} / 0$ & 114 & 44.01 & 8.593 & 301 & -3.831 & $.000 * * *$ \\
\hline & & $6 \mathrm{y} / \mathrm{o}$ & 189 & 48.21 & 9.613 & & & \\
\hline \multirow{4}{*}{$\begin{array}{l}\text { Social Competence and } \\
\text { Behavior Evaluation-30 }\end{array}$} & \multirow{2}{*}{ Anger-Aggression } & $5 \mathrm{y} / \mathrm{o}$ & 114 & 21.73 & 9.631 & 301 & 4.122 & $.000 * * *$ \\
\hline & & $6 \mathrm{y} / \mathrm{o}$ & 189 & 17.39 & 8.351 & & & \\
\hline & \multirow{2}{*}{ Anxiety-Withdrawal } & $5 \mathrm{y} / \mathrm{o}$ & 114 & 20.37 & 8.666 & 301 & 1.696 & .091 \\
\hline & & $6 \mathrm{y} / \mathrm{o}$ & 189 & 18.71 & 8.021 & & & \\
\hline \multirow{4}{*}{$\begin{array}{c}\text { Emotion Regulation } \\
\text { Checklist }\end{array}$} & \multirow{2}{*}{ Emotion Regulation } & $5 \mathrm{y} / \mathrm{o}$ & 114 & 24.85 & 3.974 & 301 & -2.460 & $.014 *$ \\
\hline & & $6 \mathrm{y} / \mathrm{o}$ & 189 & 25.47 & 4.123 & & & \\
\hline & \multirow{2}{*}{ Lability-Negativity } & $5 \mathrm{y} / \mathrm{o}$ & 114 & 27.82 & 7.262 & 301 & 3.385 & $.001 * *$ \\
\hline & & $6 \mathrm{y} / \mathrm{o}$ & 189 & 24.87 & 7.386 & & & \\
\hline
\end{tabular}

$* \mathrm{p}<.05 ; * * \mathrm{p}<.01 ; * * * \mathrm{p}<.001$

According to Table 2, average scores of the mothers did not differentiated in terms of overall parental acceptance-rejection score, "Warmth and Affection" "Hostility/Aggression", "Indifference/Neglect" and "Undifferentiated Rejection" according to age of the children ( $p>05$ ).

It has been found that Social Competence and Behavior Evaluation-30's "Social Competence" and "Anger-Aggression" subscales' scores have been significantly differentiated according to age ( $p<.001)$ whereas there was no significant difference on "Anxiety-Withdrawal" subscale ( $>.05)$. The table shows that "Social Competence" score of 6 years old children are higher than 5 years olds. On the other hand the scores of "Anger-Aggression" subscale indicate that 5 years old children display angry and aggressive behaviors more than 6 years olds.

As can be seen form Table 2, there are significant differences on the average scores of "Emotion Regulation" and "Lability-Negativity" subdimensions of Emotion Regulation Checklist according to age ( $p>.001)$. According to this result, emotion regulation skills of 6 years old children are higher than 5 years olds'. 
Table 3. Results of the correlation analysis about the relationship between maternal acceptance-rejection levels and children's social competence behaviors

\begin{tabular}{|c|c|c|c|c|}
\hline & & Social Competence & Anger-Aggression & Anxiety-Withdrawal \\
\hline \multirow{3}{*}{ Warmth and Affection } & $\mathrm{r}$ & $-115^{*}$ & $.148 *$ & .030 \\
\hline & $\mathrm{p}$ & .046 & .010 & 602 \\
\hline & $\mathrm{n}$ & 303 & 303 & 303 \\
\hline \multirow{3}{*}{ Hostility and Aggression } & $\mathrm{r}$ & -.086 & .007 & -.039 \\
\hline & $\mathrm{p}$ & .137 & .898 & .500 \\
\hline & $\mathrm{n}$ & 303 & 303 & 303 \\
\hline \multirow{3}{*}{ Indifference and Neglect } & $\mathrm{r}$ & -.070 & .026 & .028 \\
\hline & $\mathrm{p}$ & .224 & .650 & 622 \\
\hline & $\mathrm{n}$ & 303 & 303 & 303 \\
\hline \multirow{3}{*}{ Undifferentiated Rejection } & $\mathrm{r}$ & -.096 & .031 & 045 \\
\hline & $\mathrm{p}$ & .096 & .594 & 437 \\
\hline & $\mathrm{n}$ & 303 & 303 & 303 \\
\hline \multirow{3}{*}{$\begin{array}{c}\text { Parental Acceptance-Rejection } \\
\text { Questionnaire Total Score }\end{array}$} & $\mathrm{r}$ & $-.123 *$ & .074 & -.012 \\
\hline & $\mathrm{p}$ & .032 & .196 & .839 \\
\hline & $\mathrm{n}$ & 303 & 303 & 303 \\
\hline
\end{tabular}

$* \mathrm{p}<.05$

As can be seen from Table 3, where the relationship between maternal acceptance-rejection levels and children's social competence behaviors have been presented, "Warmth and Affection" subdimension of Parental Acceptance-Rejection Questionnaire has a negative significant relationship with "Social Competence" subscale of Social Competence and Behavior Evaluation-30 ( $\mathrm{r}=-.115, \mathrm{p}<.05)$; and a positive significant relationship with "Anger-Aggression" subscale ( $\mathrm{r}=.148, \mathrm{p}<.05)$.

In addition, it has been found that there is a negative significant relationship between the overall score of Parental Acceptance-Rejection Questionnaire and "Social Competence" subscale of Social Competence and Behavior Evaluation-30 ( $\mathrm{r}=-, 123, \mathrm{p}<.05)$. On the other hand, the relationships between "Hostility and Aggression", "Indifference and Neglect" and "Undifferentiated Rejection" subdimensions of Parental Acceptance-Rejection Questionnaire and "Social Competence", "Anger-Aggression" and "Anxiety-Withdrawal" subscales of Social Competence and Behavior Evaluation-30 were not found to be significantly. 
Table 4. Results of the correlation analysis about the relationship between maternal acceptance-rejection levels and children's emotion regulation skills

\begin{tabular}{|c|c|c|c|}
\hline & & Emotion Regulation & Lability-Negativity \\
\hline \multirow{3}{*}{ Warmth and Affection } & $\mathrm{r}$ & -.079 & $.128^{*}$ \\
\hline & $\mathrm{p}$ & .168 & .026 \\
\hline & $\mathrm{n}$ & 303 & 303 \\
\hline \multirow{3}{*}{ Hostility and Aggression } & $\mathrm{r}$ & -.082 & .091 \\
\hline & $\mathrm{p}$ & .155 & .115 \\
\hline & $\mathrm{n}$ & 303 & 303 \\
\hline \multirow{3}{*}{ Indifference and Neglect } & $\mathrm{r}$ & -.047 & .036 \\
\hline & $\mathrm{p}$ & .415 & .535 \\
\hline & $\mathrm{n}$ & 303 & 303 \\
\hline \multirow{3}{*}{ Undifferentiated Rejection } & $\mathrm{r}$ & $-.157 * *$ & .085 \\
\hline & $\mathrm{p}$ & .006 & .139 \\
\hline & $\mathrm{n}$ & 303 & 303 \\
\hline \multirow{3}{*}{$\begin{array}{c}\text { Parental Acceptance-Rejection } \\
\text { Questionnaire Total Score }\end{array}$} & $\mathrm{r}$ & $-.115^{*}$ & $.119^{*}$ \\
\hline & $\mathrm{p}$ & .049 & .038 \\
\hline & $\mathrm{n}$ & 303 & 303 \\
\hline
\end{tabular}

$* \mathrm{p}<.05 ; * * \mathrm{p}<.01$.

As shown in Table 4, there is a positive significant relationship between "Warmth and Affection" subdimension of Parental Acceptance-Rejection Questionnaire and "Lability-Negativity" subscale of Emotion Regulation Checklist $(\mathrm{r}=.128, \mathrm{p}<.05)$. Moreover, it has been found that there is a negative significant relationship between "Undifferentiated Rejection" subscale of Parental Acceptance-Rejection Questionnaire and "Emotion Regulation" subscale of Emotion Regulation Checklist ( $\mathrm{r}=-.157, \mathrm{p}<.01)$.

In addition, it has been found that the overall score of Parental Acceptance-Rejection Questionnaire was negatively correlated with "Emotion Regulation" subscale of Emotion Regulation Checklist $(\mathrm{r}=-.115, \mathrm{p}<.05)$ and positively correlated with "Lability-Negativity" subscale $(\mathrm{r}=.119, \mathrm{p}<.05)$.

\section{Results and Discussion}

The significant relationships observed between "Warmth and Affection" subscale of the Parental Acceptance-Rejection Questionnaire with the subscales of Social Competence and Behavior Evaluation-30, namely the negative relationship with "Social Competence" and the positive one with "Anger-Aggression", demonstrate the expected effects of parental behaviors on the social development of the child. Other studies in the literature also show that child's social competence increases as the parental care/warmth increase (Metin-Orta, Çorapçı, Yağmurlu, \& Aksan, 2013). However the definition of parental care/warmth may vary according to cultures. A study conducted in Australia revealed that positive behavior levels of both Turkish immigrant and Australian children were similar but this fact was based on different maternal behaviors in each culture. It has been found that the predictors of child's positive behavior were mother's perseverant character and warmth for the Australian group, whereas it was mother's obedience expectance for the Turkish group (Yağmurlu, Sanson, \& Köymen, 2005). The researches conducted in Turkey with preschool children and their mother also revealed positive effects of parental warmth/affection on the social competence of the children. For example, the research conducted by Gülay-Ogelman and Uçar-Çabuk (2013) with 5 years old children and their parents $(\mathrm{n}=115)$ showed that mother acceptance was determining social status of preschool children. Social status of the children, who receive higher acceptance from their parents, was higher. Similarly, in the study conducted by Tepeli and Y1lmaz (2013) with 5-6 years old children and their mothers $(\mathrm{n}=359)$, it has been found that mother's acceptance was the predictor of social problem solving skills of the child. In another study conducted by Gülay (2011) with 277 children, parental acceptation was found to be positively correlated with prosocial behaviors of the children. In the study conducted by Akçınar (2009), with 3 years old child-mother dyad $(n=123)$, it has been concluded that parental acceptation has decreased externalization behavior problems of 
the child. These studies show the role of parental behaviors on different dimensions of social development in line with the results of this research.

It has been found that overall score of Parental Acceptance-Rejection Questionnaire had a negative significant relationship with "Emotion Regulation" subdimension of Emotion Regulation Checklist and a positive significant relationship with "Lability-Negativity" subdimension. This result shows the positive and significant effect of maternal acceptance on emotion regulation skills of the child and it confirms the results of many studies reported in the literature. The study conducted by Tepeli and her collegues (2014) showed that emotion comprehension skills of preschools children, who were accepted by their mothers, were higher.

The differentiation of parental acceptance-rejection level according to gender and age of the children has been analyzed. It has been found that mothers' overall score of Parental Acceptance-Rejection Questionnaire did not change significantly according to the gender of the child. The relevant literature also shows that that mothers' acceptance-rejection level does not differentiate according to gender (Ansari, 2002; Brody et al., 2004; Çakıc1, 2006; Erkan \& Toran, 2004; Gülay-Ogelman \& Uçar-Çabuk, 2013; Toran, 2005; Yaşar, 2009). However the results of this study indicated a change of the "Warmth and Affection" subdimension of Parental Acceptance-Rejection Questionnaire in favor of the girls. T-test results of acceptance-rejection level according to age showed that acceptance level did not differentiate according to child's age. This result is in accordance with the results of the other studies investigating acceptance level according to age (Erkman \& Rohner, 2006; Veneziano, 2000).

It has been observed that there were significant differences on "Social Competence" and "Anger-Aggression" subscales of Social Competence and Behavior Evaluation-30; girls were found to be socially more competent and they show aggressive behaviors less. This result confirms the results of the studies expressing that girls are socially more competent than boys and they show aggressive behaviors less (Arslan-Yalçın, 2009; Çorapç1 et al., 2010; LaFreniere et al., 2002; Eisenberg et al., 2001). There are certain views arguing that higher social competence of the girls compared to the boys may be related to genetic effects (Macoby \& Jacklin, 1980) or family attitudes (Colder, Mott, \& Berman, 2002). The outcomes of this study can be associated with both.

"Social Competence" of the children has been analyzed according to age and a significant difference in favor of 6 years old group has been found. The outcomes of the studies conducted using Social Competence and Behavior Evaluation-30 show that participants' social competence increases as the age increases (Arslan-Yalçın, 2009; LaFreniere et al., 2002; Eisenberg et al., 2003). The increase of social competence with age may be related to child's increasing social interaction (Howes \& Phillipsen, 1998) and development of mental capacity (LaFreniere et al., 2002). This study also revealed that 5 years old children showed angry-aggressive behaviors more than 6 years olds. However, this result does not overlap with the outcomes of another study conducted with a Turkish sample, as well as the outcomes of the studies conducted with Chinese, Japanese and Brazilian samples (Çorapçı et al., 2010). The lack of differentiation observed in Anxiety-Withdrawal sub-dimension according to age is similar to many studies conducted in Turkey and over the world (LaFreniere et al., 2002; Çorapçı et al., 2010).

Another outcome of the study is indicating the effect of the age on "Emotion Regulation" and "Lability-Negativity" scores of the children. Accordingly, emotion regulation skills of 6 years old children are higher than 5 year old ones. Researches revealed that children, who recognize and understand emotions better, have more positive social behaviors and they are more popular among peers (Downs \& Strand, 2008; Y1lmaz \& Tepeli, 2013). The review of the studies conducted in Turkey with preschool children showed that emotion regulation skills (Arslan-Yalçın, 2009; Metin-Orta et al., 2013) and emotion comprehension skills (Yılmaz \& Tepeli, 2013) are related to social competence.

One of the limitations of this study is that the charecteristics of the mothers who did not want to participate in the study are unknown. Only the ones who were voluntary to participate in filled out the forms. All the mothers were from İstanbul city in Turkey. Also, the evaluation of the level of parental acceptance and rejection was performed according to mothers' perceptions. In addition, the social competence and emotion regulation skills of children were evaluated by the views of preschool teachers. Next studies could be designed by including different assesment methods from different sources together. Also, the sample could be selected from different districts of Turkey to be able to generalize the results to Turkey population.

To sum, this research shows positive and significant relationships between parental acceptance, social competence and emotion regulation skills of preschool children. The findings that point the importance of parenting, remind us the importance of supporting them. 


\section{Funding}

This research received no specific grant from any funding agency in the public, commercial, or not-for-profit sectors.

\section{References}

Akçınar, B. (2009). The effects of parental control on externalizing behaviors in early childhood (Unpublished master's thesis). Koc University, Social Sciences Institution, Istanbul, Turkey.

Altan, O. (2006). The effects of maternal socialization and temperament on children's emotion regulation (Unpublished master's thesis). Koc University, Social Sciences Institution, Istanbul, Turkey.

Anjel, M. (1993). The transliteral equivalence, reliability and validity studies of the parental acceptance-rejection questionnaire (PARQ) mother-form: A tool for assessing child abuse (Unpublished master thesis). Boğaziçi University, Institude of educational Sciences, İstanbul.

Ansari, Z. A. (2002). Parental acceptance-rejection of disabled children in non-urban Pakistan. North American Journal of Psychology, 4(1), 121-128.

Arslan-Yalçın, D. (2009). Turkish validation of Social Competence and Behavior Evaluation Scale (SCBE-30) (Unpublished master's thesis). Bogazici University, Social Sciences Institution, Istanbul, Turkey.

Ashiabi, G. S. (2000). Promoting the emotional development of preschoolers. Early Childhood Education Journal, 28(2),79-84. https://doi.org/10.1023/A:1009543203089

Batum, P., \& Yağmurlu, B. (2007). What counts in externalizing behaviors? The contributions of emotion and behavior regulation. Current Psychology: Developmental Learning Personality, 25(4), 272-294.

Bigras, M., \& Dessen, M. A. (2002). Social competence and behavior evaluation in Brazilian preschoolers. Early Education \& Development, 13(2), 140-151. https://doi.org/10.1207/s15566935eed1302_2

Bohlin, G., Hagekull, B., \& Andersson, K. (2005). Behavioral inhibition as a precursor of peer social competence in early school age: The interplay with attachment and nonparental care. Merill-Palmer Quarterly, 51(1), 1-19. https://doi.org/10.1353/mpq.2005.0001

Brody, G. H., Kim, S., McBride Murry, V., \& Brown, A. C. (2004). Protective longitudional paths linking child competence to behavioral problems among African American siblings. Child Development, 75(2), 455-467. https://doi.org/10.1111/j.1467-8624.2004.00686.x

Colder, C. R., Mott, J. A., \& Berman, A. S. (2002). The interactive effects of infant activity level and fear on growth trajectories of early childhood behavior problems. Developmental Psychopathology, 14(1), 1-23. https://doi.org/10.1017/S0954579402001013

Cole, P. M., Zahn-Waxler, C., \& Smith, K. D. (1994). Expressive control during a disappointment: Variations related to preschoolers' behavior problems. Developmental Psychology, 30(6), 835-846. https://doi.org/10.1037/0012-1649.30.6.835

Çakıc1, S. (2006). Alt ve üst sosyoekonomik düzeydeki ailelerin aile işlevlerinin, anne-çocuk ilişkilerinin ve aile işlevlerinin anne-çocuk ilişkilerine etkisinin incelenmesi [The study of the family functions, mother-child relations of lower and upper socioeconomic families and the effect of the family functions to mother-child relations] (Unpublished master's thesis). Gazi University, Educational Sciences Institution, Ankara, Turkey.

Çorapçı, F., Aksan, N., Arslan-Yalçın, D., \& Yağmurlu, B. (2010). Okul öncesi dönemde duygusal, davranışsal ve sosyal uyum taraması: Sosyal Yetkinlik ve Davranış Değerlendirme-30 Ölçeği [Emotional, behavioral and social adjusment screening at school entry: Social Competence and Behavior Evaluation-30 Scale]. Çocuk ve Gençlik Ruh Să̆lı̆̆ Dergisi/Turkish Journal of Child and Adolescent Mental Health, 17, 3-14.

Diener, M. L., \& Kim, D. Y. (2004). Maternal and child predictors of preschool children's social competence. Journal of Applied Developmental Psychology, 25(1), 3-24. https://doi.org/10.1016/j.appdev.2003.11.006

Dion, K. L., \& Yee, P. H. N. (1987). Ethnicity and personality in a Canadian context. Journal of Social Psychology, 127(2), 175-182. https://doi.org/10.1080/00224545.1987.9713677

Downs, A., \& Strand, P. (2008). Effectiveness of emotion recognition training for young children with developmental delays. Journal of Early and Intensive Behavior Intervention, 5(1), 75-89. https://doi.org/10.1037/h0100411 
Eisenberg, N. et al. (2003). Longitudional relations among parental emotional expressivity, children's regulation, and quality of socioemotional functioning. Developmental Psychology, 39(1), 3-19. https://doi.org/10.1037/0012-1649.39.1.3

Eisenberg, N. et al. (2004). The relations of effortful control and impulsivity to children's resiliency and adjustment. Child Development, 75, 25-46. https://doi.org/10.1111/j.1467-8624.2004.00652.x

Eisenberg, N., Pidada, S., \& Liew, J. (2001). The relations of regulation and negative emotionality to Indonesian $\begin{array}{lllll}\text { children's social functioning. Child Development, } & \text { 72(6), 1747-1763. }\end{array}$ https://doi.org/10.1111/1467-8624.00376

Erkan, S., \& Toran, M. (2004). Alt sosyo ekonomik düzey annelerinin çocuklarını kabul ve reddetme davranışlarının incelenmesi (Diyarbakır ili örneği) [A study on the acceptance and rejection behaviors of mothers from lower socio-economic levels (on Diyarbakır sample)]. Hacettepe Üniversitesi Ë̆itim Fakültesi Dergisi/Hacettepe University Journal of Education, 27, 91-97.

Erkman, F., \& Rohner, R. P. (2006). Youths' perceptions of corporal punishment parental acceptance and psychological adjustment in a Turkish metropolis. Cross Cultural Research, 40(3), 250-267. https://doi.org/10.1177/1069397106287924

Fox, N. A., \& Calkins, S. D. (2003). The development of self-control of emotion: Intrinsic and extrinsic influences. Motivation and Emotion, 27(1), 7-26. https://doi.org/10.1023/A:1023622324898

Gilliom, M., Shaw, D. S., Beck, J. E., Schonberg, M. A., \& Lukon, J. L. (2002). Anger regulation in disadvantaged preschool boys: Strategies, antecedents, and the development of self-control. Developmental Psychology, 38(2), 222-235. https://doi.org/10.1037/0012-1649.38.2.222

Gülay, H. (2011). Assesment of the prosocial behaviors of young children with regard to social development, social skills, parental acceptance-rejection and peer relationships. Journal of Instructional Psychology, 38(3-4), 164-172.

Gülay-Ogelman, H., \& Uçar-Çabuk, F. (2013). 5 yaş çocukların sosyal konumlarının anne babalarının kabul red düzeyleri ile ilişkisinin incelenmesi. Süleyman Demirel Üniversitesi Sosyal Bilimler Enstitüsü Dergisi/Journal of Süleyman Demirel University Institute of Social Sciences, 2(18), 23-45.

Hardy, D. F., Power, T. G., \& Jaedicke, S. (1993). Examining the relations of parenting to children's coping with everyday stress. Child Development, 64(6), 1829-1841. https://doi.org/10.2307/1131472

Howes, C., \& Phillipsen, L. (1998). Continuity in children's relations with peers. Social Development, 7(3), 340-349. https://doi.org/10.1111/1467-9507.00071

Kasuto, S. A. (2005). Aile etkileşiminin çocuğun sosyal ve bilişsel gelişimi üzerindeki etkisi [Effects of parent-child kelation on child's social and cognitive development] (Unpublished master's thesis). Marmara University, Educational Sciences Institution, Istanbul, Turkey.

Khaleque, A., \& Rohner, R. P. (2002). Perceived parental acceptance rejection and psychological adjustment: A meta analysis of cross-culturel and intra culturel studies. Journal of Marriage and Family, 64(1), 54-64. https://doi.org/10.1111/j.1741-3737.2002.00054.x

Kliewer, W., Fearnow, M. D., \& Miller, P. A. (1996). Coping socialization in middle childhood: Tests of maternal and paternal influences. Child Development, 67(5), 2339-2357. https://doi.org/10.2307/1131627

Kopp, C. B. (1989). Regulation of distress and negative emotions: A developmental view. Developmental Psychology, 25(3), 343-354. https://doi.org/10.1037/0012-1649.25.3.343

Ladd, G. W. (1999). Peer relationships and social competence during early and middle childhood. Annual Review of Psychology, 50(1), 333-359. https://doi.org/10.1146/annurev.psych.50.1.333

LaFreniere, P. J., \& Dumas J. E. (1996). Social competence and behavior evaluation in children aged 3 to 6: The short form (SCBE-30). Psychological Assessment, 8(4), 369-377. https://doi.org/10.1037/1040-3590.8.4.369

LaFreniere, P. et al. (2002). Cross-cultural analysis of social competence and behavior problems in preschoolers. Early Education \& Development, 13(2), 201-220. https://doi.org/10.1207/s15566935eed1302_6

Lemerise, E., \& Arsenio, W. (2000). An integrated model of emotion process and cognition in social information processing. Child Development, 71(1), 107-118. https://doi.org/10.1111/1467-8624.00124

Maccoby, E. E., \& Jacklin, C. N. (1980). Sex differences in aggression: A rejoinder abd reprise. Child Development, 51(4), 964-980. https://doi.org/10.2307/1129535 
Metin, İ. (2010). The effects of dispositional anger, effortful control and maternal responsiveness on turkish preschoolers' emotion regulation (Unpublished master's thesis). Koc University, Social Sciences Institution, Istanbul, Turkey.

Metin-Orta, İ., Çorapçı, F., Yağmurlu, B., \& Aksan, N. (2013). The metiational role of effortful control and emotional dysregulation in the link between maternal responsiveness and Turkish preschoolers' social competency and externalizing symptoms. Infant and Child Development, 22(5), 459-479. https://doi.org/10.1002/icd.1806

Miller, A. L., Fine, S. E., Gouley, K. K., Seifer, R., Dickstein, S., \& Shields, A. (2006). Showing and telling about emotions: Interrelations between facets of emotional competence and associations with classroom adjustment in Head Start preschoolers. Cognition and Emotion, 20, 1170-1192. https://doi.org/10.1080/02699930500405691

Morris, A. S., Silk, J. S., Steinberg, L., Myers, S. S., \& Robinson, L. R. (2007). The role of the family context in the development of emotion regulation. Social Development, 16(2), 361-388. https://doi.org/10.1111/j.1467-9507.2007.00389.x

Öner, N. (2012). Türkiye'de kullanllan psikolojik testlerden örnekler [Psychological Test Examples used in Turkey] (7th ed.). Istanbul: Boğaziçi Üniversitesi Yayınevi [Bogazici University Press].

Papps, F., Walker, M., Trimboli, A., \& Trimboli, C. (1995). Parental discipline in Anglo, Greek, Lebanese and Vietnamese cultures. Journal of Cross-Cultural Psychology, 26(1), 49-64. https://doi.org/10.1177/0022022195261004

Rohner, R. P. (1984). Handbook for the study of parental acceptance and rejection (Rev. ed.). Storrs: Center for the Study of Parental Acceptance and Rejection, University of Connecticut.

Rohner, R. P. (2004). The "parental acceptance-rejection syndrome": Universal correlates of perceived rejection. American Psychologist, 59, 830-840. https://doi.org/10.1037/0003-066X.59.8.830

Rose-Krasnor, L. (1997). The nature of social competence: A theoretical review. Social Development, 6(1), 111-135. https://doi.org/10.1111/j.1467-9507.1997.tb00097.x

Rydell, A. M., Berlin, L., \& Bohlin, G. (2003). Emotionality, emotion regulation, and adaptation among 5- to 8-year old children. Emotion, 3(1), 30-47. https://doi.org/10.1037/1528-3542.3.1.30

Shields, A., \& Cicchetti, D. (1997). Emotion regulation among school-age children: The development and validation of a new criterion Q-sort scale. Developmental Psychology, 33(6), 906-916. https://doi.org/10.1037/0012-1649.33.6.906

Tepeli, K., \& Yilmaz, E. (2013). Social problem solving skills of children in terms of maternal acceptance-rejection levels. US-China Education Review, 3(8), 581-592.

Tepeli, K., Yılmaz, E., \& Kuyucu, Y. (2014). Maternal acceptance/rejection levels and the emotion recognition skills of 5- to 6-year-old children. In M. Yaşar, Ö. Özgün, \& J. Galbraith (Eds.), Contemporary Perscpectives and Research on Early Childhood Education. Newcastle, UK: Cambrideg Scholar Publishing.

Toran, M. (2005). Farkl sosyo kültürel düzeylere sahip annelerin çocuklarını kabullenme ve reddetme davranışlarinin incelenmesi [Examination of acceptance-rejection of mothers from various socio-cultural levels concerning their children] (Unpublished master's thesis). Hacettepe University, Social Sciences Institution, Ankara, Turkey.

Veneziano, R. A. (2000). Perceived paternal and maternal acceptance and rural African American and European American youths' psychological adjustment. Journal of Marriage and the Family, 62(1), 123-132. https://doi.org/10.1111/j.1741-3737.2000.00123.x

Whiteside-Mansell, L., Bradley, R. H., \& McKelvey, L. (2009). Parenting and preschool child development: Examination of three low-income US cultural groups. Journal of Child and Family Studies, 18(1), 48-60. https://doi.org/10.1007/s10826-008-9206-1

Yağmurlu, B., \& Altan, O. (2010). Maternal socialization and child temperament as predictors of emotion regulation in Turkish preschoolers. Infant and Child Development, 19, 275-296.

Yağmurlu, B., Sanson, A., \& Köymen, S. (2005). Ebeveynlerin ve çocuk mizacının olumlu sosyal davranış gelişimine etkileri: Zihin kuramının belirleyici rolü [Effects of parenting and child temperament on the 
development of prosocial behavior: The mediating role of Theory of Mind]. Türk Psikoloji Dergisi/ Turkish Journal of Psychology, 20(55), 1-24.

Yaşar, F. (2009). İlköğretime devam eden öğrencilerin anne-çocuk ilişkisini kabul ve reddedici algllama düzeyinin annenin evlilik doyumu ve evlilik uyumu düzeyiyle ilişkisi [The level of acceptance and rejection perception of mother-child relation with the mothers' marital satisfaction and adjustmet of the students attending primary school] (Unpublished master's thesis). Cukurova University, Social Sciences Institution, Adana, Turkey.

Yılmaz, E., \& Tepeli, K. (2013). 60-72 aylık çocukların duyguları anlama becerilerinin sosyal problem çözme becerilerine etkisinin incelenmesi [Examination of social problem solving skills of 60-72 months old children in terms of their emotion understanding skılls]. Türkiye Sosyal Araştırmalar Dergisi/Turkish Journal of Social Research, 17(2), 117-130.

Zahn-Waxler, C., Friedman, R. J., Cole, P. M., Mizuta, I., \& Hiruma, N. (1996). Japanese and United States preschool children's responses to conflict and distress. Child Development, 67(5), 2462-2472. https://doi.org/10.2307/1131634

\section{Copyrights}

Copyright for this article is retained by the author(s), with first publication rights granted to the journal.

This is an open-access article distributed under the terms and conditions of the Creative Commons Attribution license (http://creativecommons.org/licenses/by/4.0/). 